\title{
A harmful traditional practice exposing young girls to experience virgin pregnancy (Shilshalo): a qualitative study in Argoba community, Amhara National Regional State, Ethiopia
}

Yohannes Mersha Belete ${ }^{1 *}$ and Negesse Kebede Atlaw ${ }^{2}$

\begin{abstract}
Background: There are various harmful traditional practices and beliefs across the different parts of Ethiopia. Shilshalo, which is yet little known about, is one of these practices existing in Argoba, a community in Amhara National Regional State of Ethiopia. This study was conducted to explore the various features associated with the practice of Shilshalo.

Methods: To address the objective of the study, qualitative approach with case study design was employed. Purposive sampling technique was used to select the participants of the study. Data were collected through interview and focus group discussion and analyzed using thematic qualitative analysis technique.

Results: This study found that Shilshalo is practiced by unmarried young boys and girls as a substitute for sexual intercourse. The actors conduct all activities performed during sexual intercourse except inserting the boy's genital organ (penis) into the girl's (vagina). The activities include warming up the girls' body by hand, kissing and brushing the girl's thigh and the areas around the outer part of the vagina with the erected penis. Shilshalo is practiced in two ways, i.e. between a boy and a girl, and between boys and a girl. This study also indicated that most members of the Argoba community including the actors consider Shilshalo as a beneficial cultural practice, yet the most shocking story is that some teenage girls experienced unwanted pregnancy without losing their virginity. In addition to virgin pregnancy, Shilshalo exposed girls to STIs, psycho-social problems and physical injuries.

Conclusion: This study concluded that Shilshalo is a harmful traditional practice that severely affects the lives of girls. The overall health and social well beings of girls are affected by different saddles that came from it. It brings almost all kinds of consequences that the other harmful traditional practices such as female genital mutilation and early marriage bring. It is also worse than the other harmful traditional practices as it poses virgin pregnancy as an additional consequence. Therefore, it is suggested that international and national organizations working on issues related to harmful traditional practice should pay due attention to Shilshalo just like what they are doing with female genital mutilation and early marriage.
\end{abstract}

Keywords: Shilshalo, Harmful traditional practice, Girls, Argoba community, Ethiopia

\footnotetext{
*Correspondence: beletemersha6@gmail.com

'Department of Gender and Development Studies, Bahir Dar University, Bahir

Dar, Ethiopia

Full list of author information is available at the end of the article
}

(c) The Author(s). 2018 Open Access This article is distributed under the terms of the Creative Commons Attribution 4.0 International License (http://creativecommons.org/licenses/by/4.0/), which permits unrestricted use, distribution, and reproduction in any medium, provided you give appropriate credit to the original author(s) and the source, provide a link to the Creative Commons license, and indicate if changes were made. The Creative Commons Public Domain Dedication waiver (http://creativecommons.org/publicdomain/zero/1.0/) applies to the data made available in this article, unless otherwise stated. 


\section{Background}

All social groups in the world have specific practices and beliefs which often have strong cultural underpinnings. These can be either positive or negative. Almost all societies have positive cultural practices that are beneficial to all members. But, there are also practices which are harmful to specific groups, for example, for women and children. These harmful cultural practices are often dubbed as Harmful Traditional Practices (HTPs) [1].

It is a mere fact that HTPs are global problems affecting millions of women and girls of all culture, religion, socio-economic strata, educational levels and other diversities [1]. HTPs pose grave consequences especially on women and girls who are subject to them. Mostly, these segments of the population face physical damage, psychological problems, health complications including sexually transmitted infection, social stigmatization, denial of educational and other opportunities, inability to control their reproductive right and the like [2]. In precise terms, HTPs are used as a weapon to keep women and girls in subordinate positions by denying their health, social, economic and human rights [3].

Even though various international, regional and national legal instruments have been used to eliminate HTPs, every year millions of women and girls across the world are still the victims of different harmful traditional practices [4]. HTPs are plenty in number, but international and national agencies have given priority only to certain types of HTPs by considering their geographical coverage. Among the recognized HTPs, dowry, female infanticide, early marriage, female genital mutilation (FGM) and inheritance marriage are the major ones [3]. However, the authors of this article believe that geographical coverage should not be the only criterion to label HTPs as major or minor social problems. Rather, HTPs that are practiced by minority groups should also get equal attention by the international and national agencies working on issues related to HTPs.

Similarly, there are several harmful traditional practices in Ethiopia; nonetheless, the nation has given emphasis only to a limited number of HTPs by considering the geographical area covered by the HTPs. In this regard, Ethiopia has identified 12 major HTPs that need intervention. These are FGM, early marriage, uvula cutting, milk teeth extraction, marriage by abduction, food prohibition, work restriction, massaging of the abdomen of pregnant women, excessive feasts, incision, and inheritance marriage [5].

The Amhara National Regional state, the second largest state of Ethiopia, on its part identified FGM, early marriage, milk teeth extraction, and uvula cutting as the major HTPs that need special focus in the region [6]. However, Shilshalo is not yet recognized as a major HTP though it has been practiced in the region for many years. The reason why the region failed to treat it together with the other four HTPs is not because it has less adverse impact on the overall wellbeing of women; rather it is practiced only by minority groups of people, namely Argoba community. Given this fact, it is hardly possible to get information about the overall features of Shilshalo. Therefore, this study attempted to generate a deep empirical investigation about the practices, consequences and causes of Shilshalo.

\section{Methodology}

\section{Description of the study area}

Argoba is one of the ethnic groups found in Amhara National Regional State of Ethiopia. The Argoba Nationality special Woreda [an autonomous administrative region or district], was founded in June 2006. It is found in South Wollo Zone of Amhara National Regional State. It is bordered with Kalu Woreda of South Wollo zone in the north and northwest, Dewa Chefa Woreda of Oromia Zone in the south, and Telalak Woreda of Afar Regional State in the east. The center of the Woreda is Medina, a small town $85 \mathrm{Kms}$ and $375 \mathrm{Kms}$ far from Dessie and Addis Ababa, respectively [7].

With an area of 30,918.70 $\mathrm{Km}^{2}$, the Argoba Nationality special Woreda consists of seven rural kebeles [the lowest administrative region under Woreda]. It is a home for about 40,000 people (22,715 Male; 17,594 Female). The community is entirely Islam. Only some of the government employers, who came from other areas, are non-Islam. With respect to the economic activity, 99.5\% of the total population is engaged in agricultural activities. Only the rest $0.5 \%$ participate in trade and other service economy [7].

\section{Research approach}

Qualitative approach was employed in this study. Among the different kinds of qualitative research designs, case study design was used since the nature of the study calls for an empirical investigation of a particular phenomenon within its real life context. Hence, exploratory case study design was used to investigate the features of Shilshalo by taking the setting and context of Argoba community into account.

\section{Data gathering instruments and data collection procedures} The information about Shilshalo was elicited from the participants of this study through in-depth interview, key informant interview, and focus group discussion. To this effect, in-depth interviews were held with 8 girls and 6 boys and semi-structured interviews were conducted with 8 key informants comprised of religious leaders, elders, and health professionals. The in-depth and semi-structure interview guidelines were developed and used only for this study purpose (See Additional file 1).

Since Shilshalo is practiced by boys and girls in the stage of puberty before marriage, the boys and girls were 
purposively selected based on two inclusion criteria: having the experience of Shilshalo and being in the age range of 15 and 18. Before interviews were held with boys and girls, written consent from their parents and oral assent from them were obtained. Each interview lasted for an hour on average. The in-depth interviews were held in Amharic. The interview focused on issues such as why and how the teenagers practiced Shilshalo and the harms it brought to them.

Key informant interviews were held with two groups of purposively selected participants including two male religious leaders, two elderly women, two elderly men and two female health professionals. The first group consisted of religious leaders, and elderly women and men who could provide explanations about the socio-cultural rationales of performing the Shilshalo. The second group involved Kebele health professionals who could clarify the potential harm of practicing Shilshalo on the wellbeing of girls. A face-to-face interview was undertaken in Amharic with each of the key informants.

To validate the interview data and to get collective information, three separate focus group discussions were conducted with girls, boys and community members. Also, three discussion guidelines were prepared for each group of discussants to properly moderate the focus group discussion (See Additional file 2). Each focus group discussion consisted of eight individuals; and in total 24 people (12 women/girls and $12 \mathrm{men} /$ boys) participated in the discussions. All focus group discussions were moderated by the researchers, and tape recording was used to capture the reflection of both interviewees and focus group discussants.

\section{Data analysis}

The data were analyzed using qualitative thematic analysis technique, involving the following stages. First, the audio recorded data gained from interview and focus group discussions were transcribed. Then, the transcribed data were translated from Amharic to English. The English version of the raw data was read repeatedly to maintain familiarity (See Additional file 3). Next to this, the data were sorted and arranged into different types depending on the sources of the information. After that, detailed analysis was done with a coding process. This involved the process of organizing the material into chunks before bringing meaning to those chunks. And, it involved taking text data in categories and labeling those categories with themes. Finally, the data were interpreted and analyzed qualitatively.

\section{Trustworthiness of the study}

Trustworthiness is seen as the strength of a research. It is used to determine whether the findings are accurate from the stand point of the researchers, the participants, or the readers of the account [8]. To ensure the trustworthiness of this qualitative study, we triangulated different data sources of information by examining evidence from the source and used it to build a coherent justification for themes. In addition to this, we used easy and simple language and description to convey the findings.

\section{Results}

\section{The practice of Shilshalo}

According to research participants, Shilshalo is a traditional sexual practice done by unmarried young boys and girls of the Argoba community. Boys and girls were playing a kind of sexual activity which is characterized with no actual insertion of the male's genital organ (penis) into the female's genital organ (vagina), but apart from this, other sexual activities are allowed in this sexual play. An old Argoba man explained this harmful traditional practice as follows.

\section{Shilshalo is a sexual play which a young unmarried girl and a young unmarried boy perform. A girl may start earlier than a boy, at 10 or 11 or 12 years age whereas the boy may start at the age of 14 years or later. They continue playing until she or he marries. Once they become friends, they play it when they get favorable conditions. When they are ready to play, they put their bodies in contact, especially making use of their hands. They also kiss each other, and finally the girl sleeps sticking her legs together, and the boy then brushes her thigh up to her vagina with his penis. He continues rubbing until he reaches at the state of orgasm and ejaculates his fluids there.}

From the above account, one can understand that the practice is done by teenagers though the starting age varies between boys and girls. The girls might begin the practice earlier than boys, which on average lies in the age range of 10 to 12 years, whereas boys usually begin at the age of 14 and above. The youngsters take this play as a means of getting sexual fantasy without considering the potential consequences that result from it. They use their body parts such as lips, hands, thighs and sexual organs to practice it. Unlike the common sexual intercourse, in Shilshalo, a boy ejaculates his sperm around the area he brushed, i.e. her thigh and areas around her vagina.

The results of this study showed that there are certain procedures followed in practicing Shilshalo. At the beginning, the boy is expected to express his love for a girl he loves. If she accepts his request, she expresses her agreement by putting jewelry on his neck or hand. Since then, they become sexual/Shilshalo/ partners so that they could practice everything that gives them sexual pleasure except practicing the actual sexual intercourse. 
This process was well articulated by the account of the following participant.

I remember how I started playing Shilshalo. When I was 13 years old, one boy approached me and asked me to be his partner. As that time, I feared to give response, so he stayed for some time with no any answer from me. On day, while I was collecting firewood, he again asked me to be his partner. At that time, I expressed my agreement by putting a Musebeha (a jewelry made from a chain of iron and used as a gift by girls to express their willingness for boys' love request) on his neck. After two years of joyful time, we separated when I married another man.

This study also found out that a boy often allows his friends to enjoy with his girlfriend. This implies that the practice of Shilshalo allows a girl to play with more than one boy. In this regard, one of the participants shared her experience as follows:

Playing Shilshalo with a lover is amusing but sometimes boys force girls to play it with their friends. In my two years stay with my boyfriend, I had encountered this problem for four times: once with a boy, once with two and twice with three of his friends. I used to enjoy when my boyfriend ejaculated his fluid on my body. However, when his friends ejaculated on my body I felt distasteful and it did not bring any joy for me. Although I disliked it too much, I did it for the sake of satisfying the interest of my boyfriend.

The above narration shows that there is a hierarchal relationship between boys and girls during Shilshalo. The boy shows his masculine behavior by forcing his girlfriend to perform it with his friends. However, girls remain submissive and for that matter they do not have the power to oppose the interest of their boyfriends. Due to this reason, therefore, most girls do Shilshalo with many boys without their consent.

\section{Consequences of Shilshalo}

The study found that Shilshalo brings devastating consequences upon the overall wellbeing of girls. The major problems are pointed out and discussed hereunder.

\section{Virgin pregnancy}

Shilshalo entertains the out flow of the male sperm on areas around the outer part of a girl's vagina. That gives the possibility of a sperm cell entering the vagina as a result of which virgin pregnancy could occur. Thus, virgin pregnancy could be taken as a unique effect of Shilshalo. This painful pregnancy was witnessed by many health professionals who were working in Argoba district. For instance, a nurse shared what she observed as follows;

I got a virgin pregnant girl when I was working at Chira Health Center in 2014. A girl who was 15 years old came to the health center with her mother. Since the girl feared to tell me what she faced, her mother began to explain what was happening on the health of her daughter. Unfortunately, all the cases she told me about her daughter could be taken as symptoms of pregnancy. Therefore, I ordered the girl to take a urine examination so as to check whether she was pregnant or not. However, her mother claimed that her daughter could never be pregnant. The mother told me that her daughter's virginity was checked by a health professional. Sadly, the urine result was positive i.e. she was virgin but pregnant. I then asked the girl if she was involved Shilshalo or not. She confirmed that she had participated in the play. Then I told the test result for her mother and explained to her as it happened due to Shilshalo. The mother was shocked and asked me to do all possible options to terminate the fetus. However, I politely advised her not to take any action; otherwise she would lose her daughter.

The narration of the above key informant reflected that Shilshalo as a sexual practice could become a cause for unintended pregnancy. The practice was done by brushing the girl's genital organ by a male's penis (without inserting the penis inside) and an outflow of a sperm cell on the exterior of the vagina. The sperm cell could then enter into the uterus via a tiny hole of virgin vagina. It is scientifically true that pregnancy might occur as long as the male sperm cell and the female cell coincide whether a female is virgin or not. That means virginity could not be a guarantee for protecting a sperm cell from entering into the uterus. It is, therefore, concluded that Shilshalo is a harmful traditional practice that exposes girls to experience virgin pregnancy.

\section{Psycho-social consequence}

Based on the findings of this study, Shilshalo brings psycho-social consequences upon girls especially on those who experience virgin pregnancy. A 16 years old virgin girl who was a victim of teenage pregnancy described her story as follows:

It was better to be silent rather than think of what happened to me. It was better for me to die. I got pregnant without losing my virginity, but nobody including my parents believed me; they just thought I was lying. They took it as a joke and blamed me as I did open sexual intercourse during Shilshalo. The only option I had was to migrate outside Ethiopia. There are 
brokers who facilitate outmigration in a hidden way. Now, I am waiting for them to do something for me.

As the experience of the above victim demonstrated, girls experiencing unintended pregnancy face stigma that comes from community members including parents. These girls were unable to cope with the societal stigma and consequently they develop multiple psychological problems such as low self-esteem, loneliness, anxiety, confusion, loss of hope, and frustration. Although the community perceives those virgin pregnant girls as if they committed open sexual intercourse, the actors responded that they were not doing open sexual intercourse rather they practice it in a very safe way since it brings societal punishment on them. This implies that Shilshalo has limited potential to expose adolescents for open sexual intercourse.

\section{Physical harm}

According to the participants of this study, teenager girls had also faced physical harm due to the practice of Shilshalo. These include body injuries, wound, and scratches by splinters, pricked by thorn and body fatigue. In line with this, a key informant woman said, "in the course of playing, there could be body injuries or wound on both of us especially when we practiced it on unsafe areas. However, girls frequently experience injuries since they often sleep on the ground while boys on top."

Another woman also shared her experience by saying:

I hated Shilshalo when I played it with my partner's friends. His friends did not worry about me. They used excessive force and make me exhausted. In spite of this hardship, I never tried to refuse this practice fearing that my boyfriend would be annoyed if I failed to satisfy his friends' needs.

From the above reflection, we could recognize that girls were facing physical injuries while they practice Shilshalo. The injury occurs due to the nature of the practice as it lets girls to practice Shilshalo with more than one boy, sleeping on the ground.

\section{Sexually transmitted infection (STI)}

As it is discussed earlier, when boys and girls do Shilshalo they use their lips and sexual organs to gratify their sexual desires. This practice would in turn expose them to be infected with sexually transmitted infection including HIV/AIDS since there was high possibility of contamination of blood and sexual fluids. A key informant nurse at Senkele Health Center described this problem by saying:

If there is bleeding or wound on their lips or areas around genital organs, STIs including HIV/AIDS can be transmitted from one person to the other. For girls, the possibility of being infected with such disease is so high since the practice is followed by the outflow of sperm cells at the gate of the vagina which may result in the inflow of sperm cells into the vagina. What I said is based on medical principle rather than by actually observing of the case as it is difficult to identify the case unlike the cases of pregnancy.

From the above idea of the health worker, one could understand that the practice had the potential to transmit STIs from one to the other. This might be worse for a girl than a boy. A boy might be exposed to STIs only if there is a wound around his penis. Whereas a girl could be more vulnerable to such problems since a male semen could easily inflow into the vagina. Moreover, the responsibility of a girl to entertain many boys has worsened the problem further.

\section{Reasons to practice Shilshalo}

According to the result of the study, most members of Argoba community had considered shilshalo as a beneficial cultural practice, only because it lets the teenagers to gratify their sexual feelings. They thought that it is useful to prepare young girls and boys for the expectation married life. That means they believed that the practice helps the youngsters to share love with their friends and at the same time to respect cultural criteria for marriage--a girl should stay virgin until marriage. It is true that in a patriarchal society, virginity of girls is associated with purity and honor but in contrast, virginity of boys is not as such an issue. Since the study community was a patriarchal community, they understood virginity in the sense of the above notion. However, the study communities, unlike the other patriarchal societies, did not believe that protecting girls from any sexual relationship with boys is not a long lasting option to keep girls' virginity because love affiliation between youngsters is a natural phenomenon. By recognizing these facts, therefore, the Argoba community had created shilshalo as means to protect girls from losing of virginity before marriage. In this regard one participant said:

In our culture, a girl must be virgin to be a wife of someone. Assume if a man married a girl with wedding ceremony and if he identified her as she is not virgin, he will immediately send her back to her families. And the girl' families will consider this as something that degraded their dignity; and she will then be discriminated by the society as she violates the norm of the society. However, our culture does not want to control sexual behavior of girls though their virginity is not compromised. Therefore, shilshalo is created as a method to make girls to be able to preserve their virginity and at the same time to perform sexual activity. 
The other reason raised for the favor of shilshalo is mothers' opinion on it. They took it as an indicator for the fate of their daughters. As to them, a girl who participate in the practice (has a boyfriend) is considered as beautiful and she will be wanted for married life. If not, it will be interpreted otherwise and she will remain unmarried. Therefore, the mothers used it to know if or not their daughters are wanted for marriage. In connection to this idea, one woman shared her experience of treating her daughters as:

I have three daughters. I have always encouraged my daughters to practice shilshalo. I take it as a means of checking the fate of my daughters in terms of accessing husbands in the near future. If my daughters do not have boyfriends, I thought they will not have a married life in the future. But if they have boyfriends, it implies that they will be wanted by males for marriage.

From the above explanation one can conclude that the mothers were those who favored shilshalo. They perceived their daughters engagement in the practice of shilshalo as a guarantee for their future married life. They assumed a girl participates in shilshalo, mean, she is a one wanted for marriage, otherwise she is considered as unfit for married life. Likewise, the information collected from the focus group discussants showed that although the mothers stand in support of the practice of shilshalo, it was difficult to say men had no role in sustaining the practice. While mothers used the practice as a means of assuring their daughters' destiny regarding married life, the fathers did not take any action on it. This indicates that the fathers had favorable attitude towards it since they did not restrict their sons and daughters to involve in the shilshalopractice.

The study also found out that Argoba girls had a positive attitude towards shilshalo. In the Argoba culture, a girl was expected to marry a person whom her families choose. This implies that she did not have a right to select whom she wanted to marry. Therefore, girls had taken 'shilshaloas an opportunity to entertain love relationship with the one they might not get in their life. One young girl clearly explained this idea by saying:

Love coupled with adolescence feeling initiated me to play shilshalo. In our culture, being a female mean, you do not have a right upon choosing your future life partner. Our families have decided all about us. As a human being we look something that could bring about joy. For example, in my case I want to marry the man I loved but my culture does not allow me to do that. So I used shilshalo to get my beloved one before I married someone that I may not like.

However, if I make an open sexual intercourse by mistake, I would lose my virginity and this would in turn create different societal problems upon me. Therefore, in order to escape from such bad condition I take care when I perform it.

The Argoba boys had also supported the practice of shilshalo but their justification is a little bit different from what the girls mentioned. In the Argoba culture, there were different expectations for a boy and a girl to engage in marriage life. The boy should be self-reliance for basic needs. Whereas a girl was expected to marry someone her families prefer. However, most of the boys found out fulfilling household materials, which are basic to live with his future wife, was a time consuming activity. Boys did not want to wait their wedding day to have sexual relationship with girls; and because of this reason they had practiced shilshalo before marriage. One of the interviewed boys strengthened this view as:

To marry a girl, I should first secure the basic goods. Once, I secured it, I can marry a girl I loved. But getting enough resource for life is a big problem for me. So that, I have used shilshalo as a way of getting sexual fantasy until I become capable enough to marry someone.

The above case stories showed that boys and girls had strong zeal to practice 'shilshalo' at their adolescent age. They explained that the practice helped them to share love with their partner before they marry someone. Especially, girls considered it as the only means to enjoy with someone she loved before marrying some other person chosen by her families. Similarly, a boy perceived it as an opportunity to satisfy his sexual desires until he became financially capable to marry a girl. Both boys and girls did not expect any harm from it as long as it was properly performed. They perceived that the harm resulted from the practice occurred due to improper practice. Otherwise, it was safe as they thought.

However, the religious leaders had openly opposed the practice. Most of Argoba community members were follower of Islamic religion and their religious leaders had often taught the community not to practice shilshalo. One of the religious leaders explained this matter by saying:

Shilshalo has been practiced by our community for ages. Our religion forbids any form of sexual practice before marriage. Even any form of relationship between young boys and girls before marriage is considered as a sin. We (religious leaders) have often preached this to our followers but most of the community members are reluctant to behave as per our teaching.

From the standpoint of the above religious leader it was possible to say that the practice does not have religious 
grounds. The Islam religion prohibited any form of sexual practice before marriage. In contrast to this religious teaching, the Argoba community has still practiced it.

\section{Discussion}

Many of the medical, psychological and epidemiological researches clearly assert that sexual experience is assumed to be inappropriate for adolescents and preserved for adults [9]. As opposed to this idea, the Argoba community promotes the early sexual experience of young boys and girls by adopting shilshalo which is an uncommon type of harmful traditional practice in the rest of the world. Shilshalo is performed by practicing all sorts of sexual activities with the exception of inserting the male genital organ (penis) into the female sexual organ (vagina). This feature of Shilshalo makes it different from masturbation since Shilshalo is a kind of sexual stimulation done between partners while masturbation is to give oneself a sexual pleasure by rubbing one's own sexual organ.

Most harmful traditional practices including FGM and early marriage have been practiced against girls with forceful action meaning that the will of girls is not respected [5]. Unlike these harmful traditional practices, Shilshalo is not practiced by forcing girls to perform it rather the option is given for them although it has negative effect on their lives. However, this does not mean that there was no family pressure on the practice. As the present study showed, the mothers were the one who encouraged their daughter to engage in Shilshalo.

Some studies conducted in Ethiopia stated that the practice of abduction is often accompanied with physical injury since the abductor uses force $[9,10]$. Similarly, girls practicing Shilshalo face physical injury especially when they do it with many boys. Most boys who perform Shilshalo with their friends' partner would use excessive physical force and make the girls to be weakened.

In some African countries, women aged 15-24 are being infected with HIV/AIDS at rates five times greater than men with the same age category. This higher rate can be described by the fact that girls are more susceptible to contracting HIV because they are married to older men due to the presence of early marriage practice $[11,12]$. This indicates that early marriage has negative health impact on young girls as it makes them vulnerable to HIV infection. Also, predisposes girls to HIV infection. The studies conducted in sub-Saharan countries revealed that the same equipment was used on 15-20 girls to mutilate their genital organs in a traditional way. And, this circumstance would, in turn, expose girls to be infected with HIV [13-15]. Similarly, the present study postulated that Shilshalo might play a role in the transmission of HIV/AIDS. It is practiced in a way that the boy ejaculates on the gate of the girl's vagina and the sperm cell then possibly flows into the inner part of the vagina and as a result of this, it gives chance for STIs including HIV/AIDS to be transmitted from one to the other especially from males to females. Apart from the STIs and related consequences, Shilshalo had also brought virgin pregnancy upon young girls. This virgin pregnancy was the very unique feature of Shilshalo and it is hard to find an HTP that has such kind of consequence all over the world. Besides, once girls experienced virgin pregnancy, they were excluded by the community and they would never marry someone else since virginity is the major prerequisite for marriage in the Argoba culture.

Almost all HTPs are done for some cultural-based reasons. For instance, the strongest reason for early marriage in Ethiopia is the desire to maintain the family's prestige and popularity. It is also practiced by some parents just to create an alliance between two families for social, political and economic reasons [6]. When we see the reason associated with the practice of FGM in Ethiopia, it is practiced for making woman to able to do proper sexual intercourse and protecting her from prostitution [6]. Regarding rationales that underpin Shishalo to become long lasting traditional practice, there were different reasons justified by the community. To mention the major ones, it was believed to be a way of maintaining girls' virginity. The mothers were also used it to cross check whether their daughter would get a husband or not in the future. When their daughters had boyfriend to practice Shilshalo, they would assume as if their daughters would surely get husbands. However, unlike the other HTPs, the victimized groups (girls and boys) were favoring the practice of Shilshalo because they considered it as an opportunity to entertain their sexual needs before marriage.

As a matter of fact, religion has strong association with HTPs especially with polygamy. The Islamic religious teachings encourage men to marry up to 4 women. In this case, religion has a direct connection with HTPs. However, the other canon of Islamic religion is that any sexual practice before marriage is forbidden [16]. Since Shilshalo is practiced before marriage, it did not get religious support rather it has been opposed by Islamic religious leaders. Given this wisdom, we can understand that religion is not always in favor of all forms of HTPs rather it depends on the nature of the HTPs.

\section{Conclusion}

Based on the findings of this study, it was concluded that Shilshalo is basically practiced in the Argoba community to preserve young girls' virginity until marriage. The community believes that restricting young girls from any sexual relationship is not a long lasting option to protect them from losing of their virginity before 
marriage, rather the community allows them to involve in a kind of sexual practice but without actual genital intercourse. While practicing Shilshalo, there is high possibility that the male's sperm enters into the vagina. As a result, there are many girls who experience virgin pregnancy and they are also exposed to sexually transmitted diseases including HIV/AIDS. Once they experience virgin pregnancy, they are excluded by the society and their fate to get a husband would be in danger. Although Shilshalo has a devastating effect on the health and overall wellbeing of young girls, it has been still considered by most of the Arogoba people including the actors as a beneficial cultural practice. Hence, it was suggested that concerned bodies should take measures to eliminate this harmful traditional practice.

\section{Additional files}

Additional file 1: In-depth and semi-structure interview guidelines used in doing conversation with interviewees and key informants. (DOCX $21 \mathrm{~kb}$ )

Additional file 2: Guidelines used in conducting discussions with focus group discussants. (DOCX $18 \mathrm{~kb}$ )

Additional file 3: Raw data used in the analysis. (DOCX $39 \mathrm{~kb}$ )

\section{Abbreviations}

FGM: Female Genital Mutilation; HIV: Human Immunodeficiency Virus: HTP: Harmful Traditional Practice; SRH: Sexual and Reproductive Health; STI: Sexual Transmitted Infection

\section{Acknowledgements}

We would like to thank all research participants who gave us valuable information about the topic of the study.

\section{Funding}

It was not funded by donor agencies or by other financial organizations.

\section{Availability of data and materials}

All data generated during this study are included in this published article and also available in its supplementary information file.

\section{Authors' contributions}

YMB and NKA had conducted interview and focus group discussion at the field work. NKA provided direction on the methodology and result sections of the manuscript. YMB developed the full manuscript by getting guidance from NKA. Both authors read and approved the final manuscript.

\section{Ethics approval and consent to participate}

The issue under the study is a sensitive issue that needs ethical consideration. Accordingly, the researchers confidentially handled the interviews and the focus group discussions. The research process began by receiving letter of ethical approval from Bahir Dar University Ethical Clearance Committee. The participants of this study were informed about the purpose of the study. The participants were also informed as they have full right to discontinue or refuse to participate in the interview or discussion. In addition, the participants were informed to be free in expressing their life experience as the information they provided would be kept confidential. Written consent was also obtained from adult participants but for those participants who were under the age of 16 oral assent and written consents were obtained from them and their parents respectively. In order to secure the identity and protect the confidentiality of the participants, the researchers did not force them to disclose their names during the interview process. In the report document, anonymity of respondents is kept by not mentioning their names.
Consent for publication

Not applicable.

\section{Competing interests}

The authors declare that they have no competing interests.

\section{Publisher's Note}

Springer Nature remains neutral with regard to jurisdictional claims in published maps and institutional affiliations.

\section{Author details}

${ }^{1}$ Department of Gender and Development Studies, Bahir Dar University, Bahir Dar, Ethiopia. ${ }^{2}$ Gender and Health Expert, Addis Ababa City Administration Rehabilitation Project Office, Addis Ababa, Ethiopia.

Received: 28 February 2018 Accepted: 29 October 2018

Published online: 20 November 2018

\section{References}

1. (UNCHR). United Nations Centre for Human Rights. In: Harmful Traditional Practices Affecting the Health of Women and Children. Geneva: Human Right Fact Sheet; 1995.

2. Kangas A, Haider H, Fraser E. Governance and Social Development Resources. In: Topic guide on gender. Birmingham: University of Birmingham; 2012

3. (UN). United Nations Organization. In: Harmful Traditional Practices Against Women and Legislation. Addis Ababa: United Nations Economic Commission for Africa; 2009.

4. (UNICEF). United Nations Children's Fund. In: The impact of harmful traditional practices on the girl child. Florence: Innocenti Research Centre; 2006.

5. (EGLDAM). Ye Ethiopia Goji Limadawi Dirgitoch Aswogaj Mahiber. In: Follow Up Survey On the Harmful Traditional Practices in Ethiopia. Addis Ababa: EGLDAM; 2012.

6. Yohannes, Mersha, Dawit, Amogne. The Society's Level of Knowlege, Attitude and Practice of Harmful Traditional Practice in Amhara Regional State, Ethiopia. Bahir Dar: ANRS Women and Children Bureau; 2016.

7. Bureau of Argoba Nationality Special Woreda Adminstration (BANSPWA). Woreda profile report. Argoba: BANSPWA; 2016. p. 12-4.

8. Creswell J. Research design: Qualitative, quantitative, and mixed methods approach. 3rd ed. Thousand Oaks: Sage Publication; 2009.

9. Fortenberry D. Puberty and adolescent sexuality. HHS Public Aceess. 2013;64(2):280-7

10. (NCTPE). National Committee on Traditional Practice in Ethiopia. In: Resource material on harmful traditional practices for policy makers. Addis Ababa: NCTPE; 2009

11. Gemechu B, Tolera A. Marriage practices among the Gidda Oromo, Northern Wollega, Ethiopia. Nordic J Afr Stud. 2006;15(3):240-55.

12. Clark S. Early marriage and HIV risks in sub-Sahran Africa. Stud Family Plann. 2004;35(3):149-60.

13. Erulkar A. Early marriage, marital relation and intimate partner violence in Ethiopia. Int Perspect Sex Reprod Health. 2013;39(1):6-13.

14. Brady M. Female genital mutilation: complications and risk of HIV transmission. AIDS Patient STDs. 1999;13(12):709-16.

15. Kinuthia R. The Association between Female Genital Mutilation(FGM) and the Risks of HIV/AIDS in Kenyan Girls and Women(15-49 Years). Georgia: Georgia State University; 2006.

16. Gizaw Y. Lived experience of polygamous marriage in Arsi zone. MA Thesis. Bahir Dar: Social Science Faculty, Bahir Dar University; 2018. 